\title{
ПРОТЕКТОРНЫЕ СВОЙСТВА ВОДОРАСТВОРИМЫХ ПОЛИМЕРНЫХ КОМПОЗИЦИЙ И ИХ ТВЕРДОФАЗНОЙ МОДИФИКАЦИИ ПРИ ПРЕДПОСЕВНОЙ ОБРАБОТКЕ ИНОКУЛИРОВАННЫХ СЕМЯН СОИ Glycine $\max (\mathrm{L}$.$) Merr.*$
}

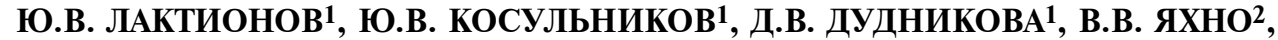 \\ А.П. КОЖЕМЯКОВ1
}

Водорастворимые полимеры в качестве прилипателей и пленкообразователей обеспечивают лучшую адгезию бактерий на семенах (по типу многокомпонентных формуляций при производстве современных химических протравителей). В этом качестве испытывались альгинат натрия низкой и высокой молекулярной массы (FMC полимер), гидроксипропилметилцеллюлоза (HPMC) (Colorcon ${ }^{\circledR}$, «Colorcon, Inc.», США), полиэтиленгликоль (ПЭГ, РЕG), карбомер (карбопол), поливиниловый спирт (PVA) и поливинилпирролидон (повидон, PVP). Более того, как оказалось, полимеры также способны удлинять период хранения биопрепаратов, повышать их совместимость с химическими средствами защиты, устойчивость к УФ-излучению, перепадам температур, высыханию, увеличивать выживаемость на поверхности семени, что позволяет производить обработку заблаговременно. Требования к создаваемым полимерным композициям - их бо́льшая эффективность по сравнению с однокомпонентными при экономичности в производстве и технологичности в применении. В настоящей работе нами впервые показано, что твердофазный компонент (активированный уголь) улучшает протективные свойства полимерной композиции при предпосевной бактериальной инокуляции семян, а из исследованных полимеров выделен поливинилпирролидон как самый эффективный протектор ризобий, применение которого позволяет увеличить допустимый интервал между инокуляцией семян и их посевом. Цель работы заключалась в комплексном исследовании водорастворимых полимеров - поливинилпирролидона, поливинилового спирта, альгината натрия и карбоксиметилцеллюлозы как добавок к инокулянту для сои на основе штамма 634б Bradyrhizobium japonicum. Инокуляции и обработке полимерными композициями подвергали семена сои сорта Белгородская 7. По результатам исследования $10 \%$ раствор поливинилпирролидона определен как наиболее эффективный среди исследованных полимеров. Его использование позволяет увеличить выживаемость клубеньковых бактерий на семенах более чем в 10 раз через 10 сут после инокуляции семенного материала. Варианты с различными концентрациями карбоксиметилцеллюлозы и альгината натрия не способны обеспечивать выживаемость бактерий на семенах более 3 сут. Возможно создание улучшенной полимерно-угольной композиции со сниженной концентрацией поливинилпирролидона (7,5 \% PVP и 5,0 \% активированного угля). Эффективность такой композиции выше, чем при использовании поливинилпирролидона без угля, и на 20-30 \% уменьшает гибель бактерий на инокулированных семенах после первых 5-7 сут хранения семян.

Ключевые слова: симбиотические азотфиксаторы, Bradyrhizobium japonicum, биопрепараты, инокуляция, соя, поливинилпирролидон, поливиниловый спирт, альгинат натрия, карбоксиметилцеллюлоза.

Соя относится к ценным бобовым культурам и имеет большое продовольственное, кормовое и агротехническое значение (1-3). Семена сои богаты легко усваиваемым белком (содержание в семенах 39-42 \%) и ценным маслом (содержание в семенах 18-23\%), а ее зеленая масса, убранная не позднее фазы налива бобов, - питательный (22-23 корм. ед. на 100 кг зеленой массы) и богатый витаминами (50-60 мг каротина на 1 кг зеленой массы) корм $(4,5)$. Благодаря интенсивной азотфиксации и высокой агротехнике возделывания соя играет положительную средообразующую роль в севооборотах и значительно повышает урожай сопутствующих культур (6, 7). Соя считается хорошим предшественником для зерновых, пропашных и кормовых культур. С агротехнологической точки зрения соя очень пластична, ее (в зависимости от агро- и почвенно-климатических условий) можно возделывать и как зерновую, и как пропашную культуру, в широких

Работа выполнена при финансовой поддержке Министерства образования и науки Российской Федерации (Соглашение № 14.607.21.0178, RFMEFI60717X0178).

1052 
пределах варьируя нормы внесения удобрений и средств защиты $(8,9)$. Большое разнообразие сортов с разной скороспелостью и требовательностью к факторам роста позволяет легко адаптировать сою к условиям выращивания. Все перечисленное позволяет рассматривать сою как универсальную культуру (10).

Важная агробиологическая особенность сои заключается в способности к формированию азотфиксирующего бобово-ризобиального симбиоза $(11,12)$. Такой симбиоз полностью обеспечивает потребности растений в азоте (13), однако столь интенсивная азотфиксация возможна лишь в оптимальных условиях, в частности при наличии в почве активных вирулентных бактерий-симбионтов сои, причем в количестве, достаточном для образования эффективного симбиоза $(14,15)$. Как правило, добиться этого можно лишь при условии искусственной предпосевной инокуляции семян сои биопрепаратами клубеньковых бактерий $(16,17)$. Важно не только правильно подобрать штамм бактерий, который будет наиболее эффективен в соответствующих почвенно-климатических условиях, но также качественно инокулировать семена таким препаратом, что для применяемых в настоящее время инокулянтов подразумевает, помимо прочего, обязательную заделку обработанных семян в день обработки (18).

На практике именно такое требование вызывает у крупных хозяйств наибольшие трудности, потому именно им зачастую и пренебрегают. Как правило, это приводит к значительному снижению эффекта от применения инокулянта, что выражается в образовании маломощной клубеньковой системы, последующем азотном голодании и в итоге в значительном недоборе урожая. В связи с этим внимание исследователей в последнее время направлено на разработку способов, позволяющих увеличить число клубеньковых бактерий на инокулированном семени на момент его заделки в почву. Одним из наиболее перспективных направлений считается сочетание полимерных растворов, выступающих в роли прилипателей, пленкообразователей и протекторов ризобий на обработанных семенах, с инокулянтом $(19,20)$. Полимерные растворы должны, во-первых, фиксировать бактерии в полимерных пленках, сохраняя тем самым как можно большее число бактерий на обрабатываемых семенах, во-вторых, повышать устойчивость бактерий к неблагоприятным факторам среды, таким как высыхание, воздействие солнечного света, перепад температур и выделение семенем токсичных для ризобий экссудатов. В совокупности такие свойства полимеров способствуют увеличению срока между инокуляцией семян и их посевом $(21,22)$.

Наиболышее распространение в качестве полимерных прилипателей в сельскохозяйственной практике получили поливинилпирролидон (повидон), поливиниловый спирт, альгинат натрия и карбоксиметилцеллюлоза (23), однако их эффективность как протекторов ризобий в целом малоизучена. Особенно остро стоит вопрос об эффективности того или иного полимера и его оптимальных концентрациях, а также о рекомендациях по его применению в качестве протектора бактерий для конкретной пары штамм ризобий-сорт.

В настоящей работе, проанализировав эффект ряда водорастворимых полимеров, мы выделили в качестве наиболее эффективного протектора ризобий поливинилпирролидон (его применение позволяет увеличить допустимый интервал между инокуляцией семян и их посевом) и впервые показали, что твердофазный компонент (активированный уголь) улучшает протективные свойства полимерной композиции при предпосевной бактериальной инокуляции семян. 
Цель работы заключалась в оценке временно́й динамики количества жизнеспособных ризобий на инокулированных семенах сои под влиянием ряда полимеров в разных концентрациях, в составе смесей различных компонентов и при оптимизации полимерных протекторов активированным углем.

Методика. Для получения биопрепарата Bradyrhizobium japonicum штамм 6346 (Ведомственная коллекция полезных микроорганизмов сельскохозяйственного назначения ФГБНУ ВНИИСХМ) выращивали в жидкой полусинтетической среде в течение 1 нед при $28^{\circ} \mathrm{C}$ с аэрацией (на шейкере) (24).

В качестве полимерных добавок к инокулянту использовали водорастворимые полимеры - поливинилпирролидон («Sigma-Aldrich», США), поливиниловый спирт PVA марки 4-98, 4-88 («Sigma-Aldrich», США), альгинат натрия («Xiamen Huaxuan Gelatin Co., Ltd», Китай) и карбоксиметилцеллюлозу (ЗАО «Карбокам», Россия), в качестве твердофазного компонента для полимерных протекторов - порошок активированного угля (марка ОУ-А, ОАО «Сорбент», Россия). Семена сои сорта Белгородская 7 инокулировали биопрепаратом следующим образом. Навески семян (25 г) помещали в чашки Петри и вносили 0,25 мл $20 \%$ суспензии штамма B. japonicum 634б. Чашки с инокулированными семенами хранили при комнатной температуре в темноте, периодически отбирая пробы для приготовления смывов (первый раз - через 1 ч после инокуляции, затем через 27, 72, 124, 168 и 240 ч.

При определения числа жизнеспособных бактерий на 1 семени сои 8 инокулированных семян, взятых из чашки Петри, помещали в пробирку с 8 мл стерильной воды и встряхивали на вортексе в течение 1 мин. Готовили серию последовательных 10-кратных разведений полученного смыва с последующим посевом на чашки Петри с агаризованной питательной средой $\left(\mathrm{K}_{2} \mathrm{HPO}_{4}-0,5\right.$ г/л, $\mathrm{MgSO}_{4} \cdot 7 \mathrm{H}_{2} \mathrm{O}-0,2$ г/л, $\mathrm{NaCl}-0,1$ г/л, дрожжевой экстракт - 1,0 г/л, маннит - 10,0 г/л, агар-агар - 16 г/л; $\mathrm{pH}=6,8-7,2)$, инкубировали при $28{ }^{\circ} \mathrm{C}$ и подсчитывали образовавшиеся колонии. На основании определения титра бактерий в смыве определяли их число в расчете на 1 инокулированное семя. Опыт выполняли в 4-кратной биологической повторности.

Статистическую обработку данных проводили с использованием программы Microsoft Excel 10. На рисунках и в таблицах представлены средние $(M)$ и стандартные ошибки средних $( \pm \mathrm{SEM})$. Различия оценивали по $t$-критерию Стьюдента и считали статистически значимыми при $\mathrm{p}<0,05$. Дисперсионный анализ полученных результатов выполнен по Б.А. Доспехову (25). В вариантах с применением в качестве протектора поливинилпирролидона разница с контролем превышала значения $\mathrm{HCP}_{05}$ и была статистически значимой.

Результаты. Поверхность семян сои представляет собой неблагоприятную среду для $B$. japonicum (рис. 1 , А). На том же рисунке изображена кривая сокращения (KC) числа живых ризобий, полученная при обработке семян сои раствором бактериальной суспензии с добавлением поливинилпирролидона в концентрации 100 г/л. Выбор поливинилпирролидона в качестве основы протектора обусловлен результатами ряда работ, приписывающих поливинилпирролидону такие свойства, как высокая адгезивность и водоудержание, а также способность защищать бактерии от токсичных семенных экссудатов и повышать общую жизнеспособность бактерий на инокулированных семенах (22).

Мы показали, что добавление поливинилпирролидона значительно 
повышает выживаемость ризобий сои на инокулированных семенах. Так, в контрольном варианте (KВ) число жизнеспособных бактерий на семенах пересекает необходимый для эффективного симбиоза порог (около 40000 КОЕ на 1 семени) за 72 ч. С поливинилпирролидоном КС за 1 сут падает до стабильного уровня в $500000 \mathrm{KOE}$ на 1 семени и не претерпевает заметного падения в течении, как минимум, 10 сут.

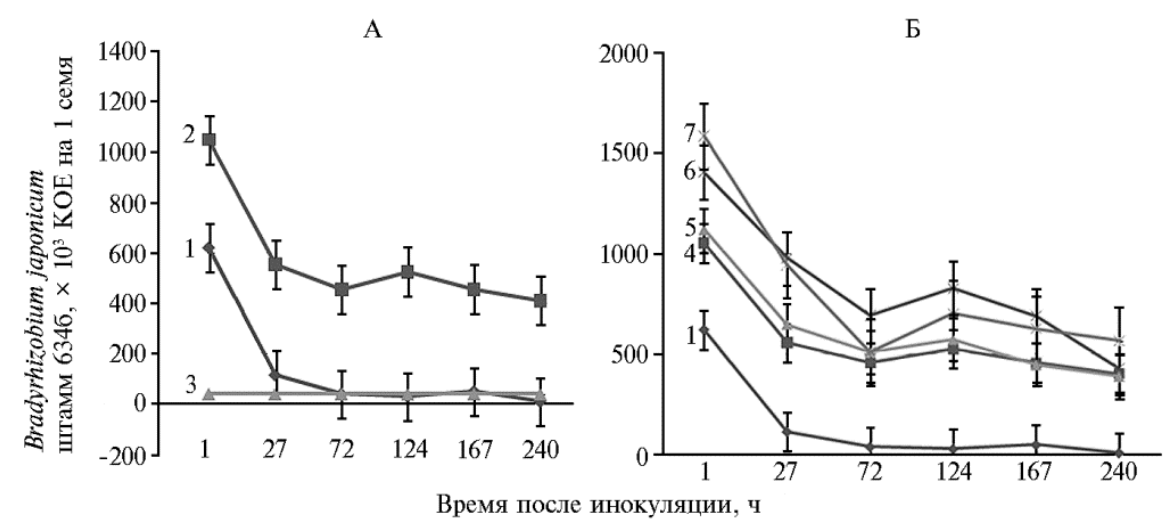

Рис. 1. Сохранность бактерий Bradyrhizobium јаропісит штамм 6346 на инокулированных семенах сои сорта Белгородская 7 в присутствии поливинилпирролидона (А) и при его сочетании с активированным углем в составе повидон-угольных композиций (Б): 1 - контроль, 2 - поливинилпирролидон (100 г/л), 3 - количество жизнеспособных ризобий на одном семени, необходимое для образования эффективного симбиоза, 4 - поливинилпирролидон (100 г/л) + активированный уголь (0 г/л), 5 - поливинилпирролидон $(100$ г/л) + активированный уголь $(25$ г/л), 6 - поливинилпирролидон $(100$ г/л) + активированный уголь (50 г/л), 7 поливинилпирролидон (100 г/л) + активированный уголь (75 г/л) (лабораторный опыт).

Успешная практика модификации полимерных растворов описана, в частности, в работе, посвященной влиянию добавок $\mathrm{ZnO}$ и $\mathrm{MgO}$ на действие карбоксиметилцеллюлозы как соединения, способствующего увеличению выживаемости клубеньковых бактерий сои при хранении в жидкой культуре (26). В нашем исследовании добавление к раствору поливинилпирролидона твердофазного наполнителя (активированный уголь) также позволило несколько повысить эффективность композиции на основе поливинилпирролидона (см. рис. 1, Б). Оптимальное количество угля в итоговом растворе составило 50 г/л.

Аналогичным образом подобрали оптимальную концентрацию поливинилпирролидона (75 г/л) в сочетании с активированным углем (50 г/л) в составе повидон-угольной композиции (рис. 2).

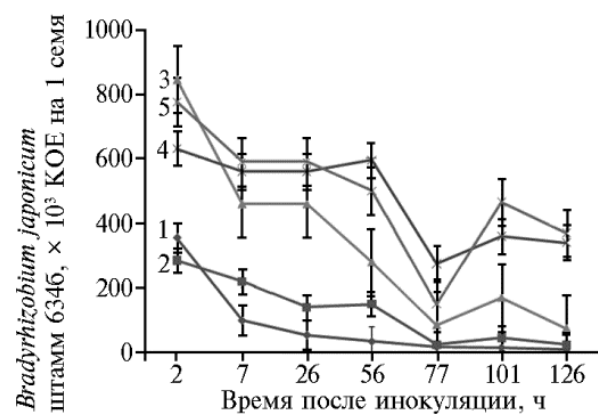

Рис. 2. Сохранность бактерий Bradyrhizobium japonicum штамм 634б на инокулированных семенах сои сорта Белгородская 7 в зависимости от состава повидон-угольных композиций: 1 - контроль, 2 - поливинилпирролидон (25 г/л) + активированный уголь (50 г/л), 3 - поливинилпирролидон (50 г/л) + активированный уголь (50 г/л), 4 - поливинилпирролидон (75 г/л) + активированный уголь (50 г/л), 5 - поливинилпирролидон (100 г/л) + активированный уголь (50 г/л) (лабораторный опыт).

Таким образом, результаты наших экспериментов показали высокую эффективность поливинилпирролидона в качестве полимерной основы протектора ризобий, однако его сравнительно высокая стоимость существенно 
ограничивает возможности промышленного производства протектора на его основе. В связи с этим мы сравнили ряд дешевых полимеров-аналогов, получивших распространение в сельском хозяйстве в качестве прилипателей и потенциально способных заменить (полностью или частично) дорогой поливинилпирролидон в составе полимер-угольной композиции.

Один из таких аналогов - поливиниловый спирт, который описан как инкапсулирующий семена полимер, способствующий повышению устойчивости клубеньковых бактерий к стресс-факторам (27). Поливиниловые спирты обоих марок изучили по аналогичной для поливинилпирролидона методике (табл. 1). Как оказалось, поливиниловый спирт, хотя и увеличивает выживаемость ризобий на семенах, значительно уступает в эффективности поливинипирролидону.

1. Сохранность бактерий Bradyrhizobium japonicum штамм 634 на инокулированных семенах сои сорта Белгородская 7 в присутствии поливинилового спирта ( $10^{3} \mathrm{KOE}$ на 1 семя, $N=4$, лабораторный опыт)

\begin{tabular}{|c|c|c|c|c|c|c|}
\hline \multirow{2}{*}{$\begin{array}{l}\text { Время после } \\
\text { инокуляции, ч }\end{array}$} & \multicolumn{6}{|c|}{ Вариант } \\
\hline & контроль & 50 г/л & 75 г/л & 100 г/л & 200 г/л & $\mathrm{HCP}_{05}$ \\
\hline \multicolumn{7}{|c|}{ Пол и в и н ил о вы й $\quad$ с п и р т PVA 4-98 } \\
\hline 1 & $255 \pm 12,1$ & $300 \pm 13,4$ & $470 \pm 18,2$ & $580 \pm 23,6$ & $845 \pm 31,7$ & 35,40 \\
\hline 19 & $25 \pm 1,1$ & $25 \pm 1,2$ & $30 \pm 1,7$ & $55 \pm 2,1$ & $105 \pm 4,2$ & 5,08 \\
\hline 66 & 0 & 0 & 0 & $5 \pm 0,9$ & $20 \pm 1,4$ & 2,45 \\
\hline 93 & 0 & $15 \pm 0,7$ & 0 & 0 & 0 & 0 \\
\hline \multicolumn{7}{|c|}{ Пол и в и н и ло в ы й с п и р т PVA 4-88 } \\
\hline 3 & $85 \pm 3,3$ & $180 \pm 4,2$ & $255 \pm 6,7$ & $305 \pm 7,4$ & $425 \pm 9,5$ & 8,97 \\
\hline 50 & 0 & 0 & 0 & 0 & 30 & 0 \\
\hline 76 & 0 & 0 & 0 & 0 & 10 & 0 \\
\hline
\end{tabular}

В качестве полимерных протекторов мы также протестировали карбоксиметилцеллюлозу и альгинат натрия. Выбор этих полимеров был обусловлен сообщениями об их благоприятном влияние на жидкую культуру клубеньковых бактерий в процессе хранения (23). Для альгината натрия показана способность поддерживать жизнеспособность ростостимулирующих бактерий на инокулированных стеклянных шариках в течение более 14 лет (28). Однако в наших опытах эффект от применения карбоксиметилцеллюлозы и альгината натрия как протекторов для бактерий оказался весьма незначительным (табл. 2).

2. Сохранность бактерий Bradyrhizobium japonicum штамм 6346 на инокулированных семенах сои сорта Белгородская 7 в присутствии карбоксиметилцеллюлозы и альгината натрия ( $10^{3} \mathrm{KOE}$ на 1 семя, $N=4$, лабораторный опыт)

\begin{tabular}{|c|c|c|c|c|c|c|}
\hline \multirow{3}{*}{$\begin{array}{l}\text { Время после } \\
\text { инокуляции, ч }\end{array}$} & \multicolumn{6}{|c|}{ Вариант } \\
\hline & \multirow{2}{*}{ контроль } & \multicolumn{2}{|c|}{ карбоксиметилцеллюлоза } & \multicolumn{2}{|c|}{ альгинат натрия } & \multirow{2}{*}{$\mathrm{HCP}_{0}$} \\
\hline & & 25 г/л & 50 г/л & 25 г/л & 50 г/л & \\
\hline$\overline{3}$ & $105 \pm 3,7$ & $155 \pm 4,6$ & $175 \pm 4,2$ & $215 \pm 8,4$ & $478 \pm 11,7$ & 10,58 \\
\hline 50 & $25 \pm 3,4$ & $98 \pm 6,9$ & $150 \pm 8,4$ & $200 \pm 12,1$ & $153 \pm 9,8$ & 20,26 \\
\hline 76 & 0 & $5 \pm 0,9$ & $34 \pm 1,7$ & $9 \pm 1,2$ & $71 \pm 3,1$ & 1,04 \\
\hline
\end{tabular}

Кроме того, отметим, что альгинат натрия и в особенности карбоксиметилцеллюлоза загущают растворы гораздо сильнее, чем поливинилпирролидон в тех же концентрациях, следовательно, эти полимеры не только неэффективны как протекторы ризобий, но и значительно менее технологичны. В работе других авторов также показано, что альгинат натрия и карбоксиметилцеллюлоза, успешно поддерживающие жизнеспособность бактерий в жидкой культуре в процессе хранения, оказались неэффективными протекторами на семенах (23). В этом же исследовании поливинилпирролидон был исключительно эффективным полимерным протектором ризобий на семенах, но угнетал бактерий в процессе хранения в 
жидкой культуре (23). В то же время сообщалось, что в концентрации $4 \%$ поливинилпирролидон успешно защищает клетки Azotobacter vinelandii в жидкой культуре при долгом хранении (29), описано благотворное влияние поливинилпирролидона на хранящуюся культуру клубеньковых бактерий (30), что может указывать на видовую (штаммовую) специфичность действия полимера на бактериальные культуры.

Учитывая высокую стоимость поливинилпирролидона, мы изучили возможность его хотя бы частичного замещения альгинатом натрия и карбоксиметилцеллюлозой в составе полимер-угольной композиции (рис. 3).

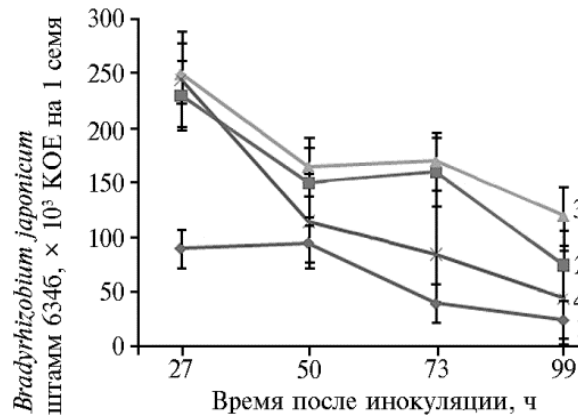

Рис. 3. Сохранность бактерий Bradyrhizobium japonicum штамм 6340 на инокулированных семенах сои сорта Белгородская 7 в вариантах с частичным замещением поливинилпирролидона в составе повидон-угольных композиций на карбоксиметилцеллюлозу и альгинат натрия: 1 - контроль, 2 - поливинилпирролидон (25 г/л) + активированный уголь (50 г/л), 3 - поливинилпирролидон (25 г/л) + активированный уголь (50 г/л) + карбоксиметилцеллюлоза (50 г/л), 4 - поливинилпирролидон (25 г/л) + активированный уголь (50 г/л) + альгинат натрия (50 г/л) (лабораторный опыт).

Добавление альгината натрия в повидон-угольную композицию несколько снизило эффект последней, а карбоксиметилцеллюлоза практически не изменила ее эффективности, что указывает на невозможность даже частичной замены поливинилпирролидона в составе повидон-угольной композиции иным полимером.

Итак, поверхность семян сои представляет собой неблагоприятную среду для штамма 634б Bradyrhizobium japonicum: число этих бактерий в расчете на одно инокулированное семя падает с 620 тыс. (1 ч после обработки) до 115 тыс. (27 ч после обработки). Гибель бактерий можно существенно замедлить, применяя полимерные добавки к инокулянту. Самым эффективным протектором ризобий среди исследованных полимеров был поливинилпирролидон: при его применении в концентрации 100 г/л на одном семени сохранялось 500 тыс. жизнеспособных ризобий на протяжении 10 сут. Полимерную основу этого протектора можно модифицировать активированным углем, что усиливает действие повидон-угольной композиции в 1,5-2,0 раза (оптимальная концентрация повидона в композиции - 75 г/л, активированного угля - 50 г/л). Возможные полные или частичные заменители повидона (поливиниловый спирт, альгинат натрия, карбоксиметилцеллюлоза) в предлагаемой композиции не проявили эффективности.

\footnotetext{
ФГБНУ Всероссийский НИИ сельскохозяйственной микробиологии,

196608 Россия, г. Санкт-Петербург-Пушкин, ш. Подбельского, 3, e-mail: Laktionov@list.ru, kullavayn@gmail.com $₫$, vyachno@yandex.ru, kojemyakov@rambler.ru;

2Филиал «Экос»ФГБНУ Всероссийский НИИ

сельскохозяйственной микробиологии,

196608 Россия, г. Санкт-Петербург-Пушкин, ш. Подбельского 3, e-mail: vyachno@yandex.ru
}

Поступила в редакцию 12 июля 2019 года 


\title{
COMPOSITIONS AND THEIR SOLID-PHASE MODIFICATION
}

\author{
Yu.V. Laktionov', Yu.V. Kosulnikov', D.V. Dudnikova', V.V. Yahno², \\ A.P. Kojemyakov ${ }^{1}$
}

${ }^{1}$ All-Russian Research Institute for Agricultural Microbiology, 3, sh. Podbel'skogo, St. Petersburg, 196608 Russia, e-mail laktionov@list.ru, kullavayn@gmail.com ( $₫$ corresponding author), vyachno@yandex.ru, kojemyakov@rambler.ru;

${ }^{2}$ Ekos Branch, All-Russian Research Institute for Agricultural Microbiology, 3, sh. Podbel'skogo, St. Petersburg, 196608 Russia, e-mail vyachno@yandex.ru

ORCID:

Laktionov Yu.V. orcid.org/0000-0001-6241-0273

Kosulnikov Yu.V. orcid.org/0000-0003-1134-3503

Dudnikova D.V. orcid.org/0000-0002-4319-1957

Yahno V.V. orcid.org/0000-0001-7953-3405

Kojemyakov A.P. orcid.org/0000-0002-9657-2454

The authors declare no conflict of interests

Acknowledgements:

Supported financially by the Ministry of Education and Science of the Russian Federation (Agreement № 14.607.21.0178, RFMEFI60717X0178)

Received July 12, 2019

doi: 10.15389/agrobiology.2019.5.1052eng

\section{Abstract}

The effectiveness of some water-soluble polymers as film-forming agents that provide better adhesion of bacteria to seeds (like multicomponent formulations in modern chemical dressings) remains practically relevant. The likely candidate adhesives are low and high molecular weight sodium alginate (FMC polymer), hydroxypropyl methylcellulose (HPMC) (Colorcon ${ }^{\circledR}$, Colorcon, Inc., USA), polyethylene glycol (PEG), carbomer-carbopol 940 (Necardis SA), polyvinyl alcohol (PVA) and polyvinylpyrrolidone (povidone, PVP) (K15). Film-forming polymers can also improve the shelflife of biologicals, their compatibility with chemical protective agents and resistance to UV radiation, temperature extremes and drying, thus increasing survival of bacteria on the surface of inoculated seeds. These allow practitioners to carry out seed pre-sowing inoculation beforehand. Developed polymer compositions should be more effective than single-component, provided that they remain cost-effective and convenient for practical use. This paper is the first to report the effects of various polymer combinations on inoculated seeds and the improvement of protective properties of the water-soluble polymers by activated charcoal, a solid-phase component. Among the polymers tested, polyvinylpyrrolidone is revealed to be the most effective for rhizobial survival due to longer allowable interval between seed inoculation and sowing. Our objective was to compare survival rate of Bradyrhizobium japonicum 634b inoculum for soybean cv. Belgorodskaya 7 seeds as influenced by water-soluble polymers polyvinylpyrrolidone, polyvinyl alcohol, sodium alginate and carboxymethylcellulose as additives. Our findings indicate that $10 \%$ polyvinylpyrrolidone solution is the most effective among the studied polymers. Its use increases more than 10-fold the survival of nodule bacteria on seeds 10 days after inoculation of seed material. Variants with different concentrations of carboxymethyl cellulose and sodium alginate do not ensure bacterial survival on seeds for more than 3 days. It is possible to create an effective polymer-carbon composition with a lower concentration of polyvinylpyrrolidone (7.5\% polyvinylpyrrolidone and $5.0 \%$ activated charcoal). This composition is more effective than polyvinylpyrrolidone without coal, and provides a 20-30\% reduction in bacterial death on inoculated seeds after the first 5-7 days of seed storage.

Keywords: symbiotic nitrogen, Bradyrhizobium japonicum, inoculation, soybean, polyvinylpyrrolidone, polyvinyl alcohol, sodium alginate, carboxymethylcellulose.

\section{REFERENCES}

1. Regar M.K., Meena R.H., Jat G., Mundra S.L. Effect of different rhizobial strains on growth and yield of soybean [Glycine max (L.) Merrill]. International Journal of Current Microbiology and Applied Sciences, 2017, 6(11): 3653-3659 (doi: 10.20546/ijcmas.2017.611.427).

2. Vavilov P.P., Posypanov G.S. Bobovye kul'tury i problema rastitel'nogo belka [Legumes and the problem of vegetable protein]. Moscow, 1983 (in Russ.).

3. De Micco V., Buonomo R., Paradiso R., De Pascale S., Aronne G. Soybean cultivar selection for Bioregenerative Life Support Systems (BLSSs): theoretical selection. Advances in Space Research, 2012, 49: 1415-1421 (doi: 10.1111/plb.12056).

4. Lamptey S., Ahiabor B.D.K., Yeboah S., Asamoah C. Response of soybean (Glycine max) to rhizobial inoculation and phosphorus application. Journal of Experimental Biology and Agricultural Sciences, 2014, 2(1): 72-77.

5. Agafonov E.V., Guzhvin S.A. Kormoproizvodstvo, 2004, 11: 14-16 (in Russ.).

6. Zavalin A.A., Blagoveshchenskaya G.G., Kozhemyakov A.P. V sbornike: Innovatsionnotekhnologicheskie osnovy razvitiya zemledeliya [In: Innovative technological basis for the development of agriculture]. Kursk, 2006: 312-315 (in Russ.).

7. Kokorina A.L., Kozhemyakov A.P. Bobovo-rizobial'nyi simbioz i primenenie mikrobiologicheskikh 
preparatov kompleksnogo deistviya - vazhnyi rezerv povysheniya produktivnosti pashni [Legumerhizobial symbiosis and complex microbiological preparations are an important reserve to increase arable land productivity]. St. Petersburg, 2010 (in Russ.).

8. Argaw A. Response of soybean to inoculation with Bradyrhizobium spp. in saline soils of Shinille Plains, Eastern Ethiopia. East African Journal of Sciences, 2014, 8(2): 79-90.

9. Sinegovskaya V.T., Gaiduchenko A.N. Zemledelie, 2010, 5: 27-29 (in Russ.).

10. Vollmann J. Soybean versus other food grain legumes: a critical appraisal of the United Nations International Year of Pulses 2016. Die Bodenkultur: Journal of Land Management, Food and Environment, 2016, 67(1): 17-24 (doi: 10.1515/boku-2016-0002).

11. Provorov N.A. Izvestiya AN SSSR, ser. Biol., 1991, 1: 77-87 (in Russ.).

12. Dart P.J., Wani S.P., Giller K.E., Kipe-Nolt J., Day J.M., Avalakki J.M., Upadhyya M.N., Hebbar P., Chandrapalaiah S.C. Nitrogen fixation associated with sorghum and pearl millet. In: Australia Institute of Agricultural Science AIAS Occasional Publication No. 12: Proc. of the Seventh Australian Legume Nodulation Conference. Sydney, 1984: 111-113 (doi: 10.13140/2.1.1790.3368).

13. Unkovich M.J., Pate J.S. An appraisal of recent measurements of symbiotic $\mathrm{N}_{2}$ fixation by annual legumes. Field Crops Research, 2000, 65(2-3): 211-228 (doi: 10.1016/S0378-4290(99)00088-X).

14. Hardy R.W.F., Bums R.C., Holstein R.D. Application of the acetylene reduction assay for measurement of nitration. Soil Biology and Biochemistry, 1973, 5: 47-81.

15. Patra R.K., Pant L.M., Pradhan K. Response of soybean to inoculation with rhizobial strains: effect on growth, yield, N uptake and soil N status. World Journal of Agricultural Sciences, 2012, 8(1): 51-54.

16. Clúa J., Roda C., Zanetti M.E., Blanco F.A. Compatibility between legumes and rhizobia for the establishment of a successful nitrogen-fixing symbiosis. Genes (Basel), 2018, 9(3): 125 (doi: 10.3390/genes9030125).

17. Al-Falih A.M.K. Factors affecting the efficiency of symbiotic nitrogen fixation by Rhizobium. Pakistan Journal of Biological Sciences, 2002, 5(11): 1277-1293 (doi: 10.3923/pjbs.2002.1277.1293).

18. Vashan Y., Bashan L., Prabhu S.R., Hernandez J. Advances in plant growth-promoting bacterial inoculant technology: formulations and practical perspectives (1998-2013). Plant and Soil, 2014, 378: 1-33 (doi: 10.1007/s11104-013-1956-x.)

19. Grishechkin V.V., Golovina E.V. Zernobobovye i krupyanye kul'tury, 2014, 1(9): 41-44 (in Russ.).

20. Stupina L.A., Mosina A.S. Vestnik KrasGAU, 2016, 3: 84-89 (in Russ.).

21. Głodowska M., Schwinghamer T., Husk B., Smith D. Biochar based inoculants improve soybean growth and nodulation. Agricultural Sciences, 2017, 8(9): 1048-1064 (doi: 10.4236/as.2017.89076).

22. Tittabutr P., Payakapong W., Teaumroong N., Singleton P., Bookerd N. Growth, survival and field performance of Bradyrhizobial liquid inoculant formulations with polymeric additives. ScienceAsia, 2007, 33: 69-72 (doi: 10.2306/scienceasia1513-1874.2007.33.069).

23. Rivera D., Obando M., Barbosa H., Rojas-Tapias D., Bonilla Buitrago R. Evaluation of polymers for the liquid rhizobial formulation and their influence in the Rhizobium-Cowpea interaction. Universitas Scientiarum, 2014, 19(3): 265-275 (doi: 10.11144/Javeriana.SC19-3.eplr).

24. Kosul'nikov Yu.V., Laktionov Yu.V. Factors which influence toxicity of legume seed disinfectants towards biologicals based on symbiotic nitrogen fixers. Agricultural Biology [Sel'skokhozyaistvennaya biologiya], 2018, 53(5): 1037-1044 (doi: 10.15389/agrobiology.2018.5.1037eng).

25. Dospekhov B.A. Metodika polevogo opyta [Methods of field trials]. Moscow, 2012 (in Russ.).

26. Paulo I., Fernandes J., Tiago G., Oliveira P., Ribeiro G.X., Rumjanek N.G. Polymers as carriers for rhizobial inoculant formulations. Pesquisa Agropecuária Brasileira, 2009, 44(9): 11841190 (doi: 10.1590/S0100-204X2009000900017).

27. Damasceno R., Roggia I., Pereira C., Sá E. Rhizobia survival in seeds coated with polyvinyl alcohol (PVA) electrospun nanofibres. The Canadian Journal of Microbiology, 2013, 59(11): 716719 (doi: 10.1139/cjm-2013-0508).

28. Bashan Y., Gonzalez L.E. Long-term survival of the plant-growth-promoting bacteria Azospirillum brasilense and Pseudomonas fluorescens in dry alginate inoculant. Applied Microbiology and Biotechnology, 1999, 51(2): 262-266 (doi: 10.1007/s002530051391).

29. Mounika N., Muralidhara Rao D., Uma A., Ali S. Effect of different chemical additives on growth of Azotobacter vinelandii. International Journal of Scientific Research and Management, 2018, 6(03): B-2018-24-26 (doi: 10.18535/ijsrm/v6i3.b03).

30. Sehrawat A., Suneja S., Yadav A., Anand R.C. Influence of different additives on shelf life of Rhizobial inoculants for mungbean (Vigna radiata L.). International Journal of Recent Scientific Research, 2015, 6(5): 4338-4342. 